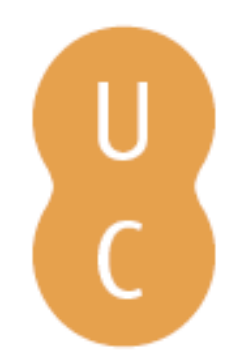

\title{
nombalina
}

\section{Retórica e política no ocaso do império: António Pinheiro de Porto de Mós, humanista e orador da coroa}

\author{
Autor(es): $\quad$ André, Carlos Ascenso \\ Publicado por: Imprensa da Universidade de Coimbra \\ URL \\ persistente: URI:http://hdl.handle.net/10316.2/38967 \\ DOI: $\quad$ DOI:http://dx.doi.org/10.14195/978-989-26-0395-7_21 \\ Accessed : $\quad$ 26-Apr-2023 15:06:11
}

A navegação consulta e descarregamento dos títulos inseridos nas Bibliotecas Digitais UC Digitalis, UC Pombalina e UC Impactum, pressupõem a aceitação plena e sem reservas dos Termos e Condições de Uso destas Bibliotecas Digitais, disponíveis em https://digitalis.uc.pt/pt-pt/termos.

Conforme exposto nos referidos Termos e Condições de Uso, o descarregamento de títulos de acesso restrito requer uma licença válida de autorização devendo o utilizador aceder ao(s) documento(s) a partir de um endereço de IP da instituição detentora da supramencionada licença.

Ao utilizador é apenas permitido o descarregamento para uso pessoal, pelo que o emprego do(s) título(s) descarregado(s) para outro fim, designadamente comercial, carece de autorização do respetivo autor ou editor da obra.

Na medida em que todas as obras da UC Digitalis se encontram protegidas pelo Código do Direito de Autor e Direitos Conexos e demais legislação aplicável, toda a cópia, parcial ou total, deste documento, nos casos em que é legalmente admitida, deverá conter ou fazer-se acompanhar por este aviso.

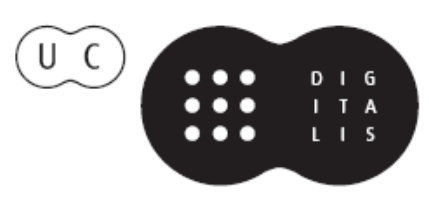


Nair de Nazaré Castro Soares

Santiago López Moreda

Coordenação

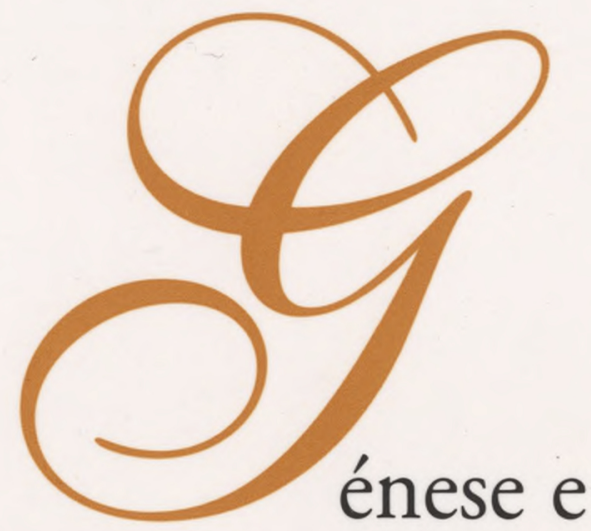

Consolidação da Ideia de Europa

Vol. IV

Idade Média e Renascimento

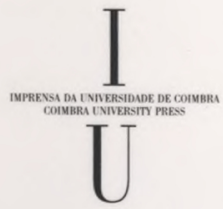

- COIMBra 2009 


\title{
RETÓRICA E POLÍTICA NO OCASO DO IMPÉRIO: António Pinheiro de Porto de Mós, humanista e orador da Coroa ${ }^{1}$
}

\author{
CARLOS ASCENSO ANDRÉ \\ (Universidade de Coimbra)
}

Tempo de passagem ou época de charneira, assim se pode, com toda a justiça, definir o século XVI português. Dir-se-á que essa é a marca iniludível - de todos os momentos históricos, que todo o presente é, por definição, o instante em que do passado se transita para o porvir. Será. Mas fazer essa afirmação a respeito do nosso século XVI é mais do que flor de retórica ou ornato de estilo.

$\mathrm{Na}$ encruzilhada entre a Idade Média e a modernidade, que, com o Renascimento, se inaugurava, Portugal viveu, ao longo de Quatrocentos e Quinhentos, sob a força de atracções múltiplas de sinais contrários. Pais de finisterra que é, como o nosso épico, ele mesmo um quinhentista, retratava, com propriedade - "onde a terra se acaba e o mar começa" -, Portugal herdava, de dois séculos e meio de história, duas gestas de sinal oposto: a luta pela definição e afirmação de um território, por um lado, com tudo quanto nessa palavra se encerra, e, logo depois, o desejo de expansão para além da única fronteira natural que lhe fora imposta, ou seja, para além do oceano. Mas herdara, também, desde o Infante D. Pedro, pelo menos, uma outra ambição, um outro projecto: a expansão dos seus horizontes culturais, ideológicos, em direç̧ão ao continente que para alhures se estendia, além Pirinéus, num fascínio de quem busca, à uma, o desconhecido e a raiz.

Não se circunscreve, porém, ao espaço ou ao território a encruzilhada do Renascimento. Ao longo do século XV, a Idade Média, com tudo o que a caracterizava, fora findando, pouco a pouco, como sempre acontece no devir

O presente trabalho tem por base a comunicação apresentada, como conferência de encerramento, ao Congresso Sete marcos, sete séculos, realizado em Porto de Mós, a 17 e 18 Junho 2005 e cujas actas não foram ainda publicadas. A esse texto, procedeu-se, apenas, a algumas alterações de pormenor. 
histórico, para dar lugar a novas interrogações, novos rumos, novos modelos, que viriam a alcançar, séculos depois, o justo título de "modernidade". Essa busca, porém, que questionava o presente e lançava pontes sobre o futuro, não se fazia sem uma outra indagação, não menos atenta e lúcida, sobre outras raízes, em passado bem longínquo: a antiguidade clássica, greco-latina, matriz da identidade dos povos ocidentais.

O homem do Renascimento é assim mesmo, como dizia Donald Kelley: alguém que, de pés firmes no presente, questiona o seu passado, com os olhos postos no futuro. ${ }^{2}$

Era essa, em síntese, a encruzilhada em que se debatia o Portugal dos séculos XV e XVI: firmado no seu território, que os reis da primeira dinastia haviam consolidado, alongava o passo a terras distantes, além-mar, mas estendia-os, igualmente, continente adentro, na busca do diálogo que lhe faltava com essa Europa em mudança; firmado no presente, nele procurava lançar as sementes de um futuro novo e diferente, sementes essas que buscava no passado remoto, com a consciência lúcida e crítica de que não há futuro sem raiz.

De tudo isso era retrato o país, ponto de encontro de povos, civilizações, pessoas, costumes, das mais variadas proveniências. Afinal de contas, Portugal era, já então, a fronteira entre o velho e o novo mundo. De país de finisterra, havia-se convertido em cais de embarque e desembarque, o mesmo é dizer, ponto de passagem.

São, convenhamos, caminhos complementares. Assim o sentiram, com inteira justeza e pertinência, os maiores vultos da nossa história cultural de Quinhentos, de que Camões é, tão-somente, o paradigma, por ser a sua expressão poética.

Deixemos, porém, de lado a busca que orientou os nossos navegantes até novos destinos e centremos a atenção nessas duas outras procuras, igualmente complementares, a que levou rumo à Europa e a que conduziu à descoberta da Antiguidade.

Desde finais do século $\mathrm{XV}$, muitos foram os Portugueses que rumaram aos grandes centros de saber e cultura que, então, floresciam na Europa, onde pontificavam os mais ilustres vultos do Renascimento: Paris, Toulouse, Florença, Bolonha, Ferrara, Montpellier vieram somar-se a Salamanca e a Madrid (Alcalá de Henares), como destino dos nossos escolares. Henrique Caiado, D. João Rodrigues de Sá de Meneses, Sá de Miranda, Diogo de Gouveia e, depois, os seus sobrinhos André, Marcial e António, André de Resende, Diogo

${ }^{2}$ D. R. KELLEY, Renaissance Humanism. Boston, Mss., Twayne Publishers, $1991, \mathrm{x}$. 
de Teive, Aires Barbosa, Diogo Pires, Damião de Góis e tantos, tantos outros apreenderam, nas principais universidades da Europa, os novos rumos da cultura europeia, granjearam prestigio além-fronteiras, onde, depois de terem sido alunos brilhantes, se volveram em mestres admirados e respeitados. Alguns por lá ficaram a exercer o seu magistério, outros retornaram ao país, assim importando os fundamentos de uma cultura que (re)nascia.

Preocupações de natureza cultural tornaram-se um emblema de reis e príncipes. Os melhores mestres europeus, fossem eles estrangeiros ou portugueses, eram contratados como preceptores de príncipes ou dos filhos da mais destacada nobreza. D. João II, por exemplo, convidou Cataldo Parísio Sículo, um humanista italiano, para preceptor do seu filho natural, D. Jorge, que ele tinha, no seu íntimo, designado para lhe suceder no trono. E muitos outros the seguiram o exemplo.

A Coroa, aliás, estimulava e incentivava este vai-vem cultural. Neste particular, D. João III fica para a história como o monarca que melhor soube desenvolver uma política de efectivo e consequente apoio à formação de elites de letrados e homens de cultura. Muitos foram, durante o seu reinado, os "bolseiros de El-Rei", como a história veio a designá-los, e que frequentaram as melhores universidades da Europa, com especial destaque para Paris, onde o Rei criou o Colégio de Santa Bárbara, que albergou muitos daqueles cujos estudos a Coroa patrocinou, entre eles os Gouveias (tio e sobrinhos), Teive, António Pinheiro, por exemplo. Com eles, vieram, depois, para Portugal, para a Universidade, já, então, em Coimbra, ou para o Colégio das Artes ou para outras instituições de ensino, alguns mestres estrangeiros de excelência, como, por exemplo, Vicente Fabrício ou Jorge Buchanan. ${ }^{3}$

${ }^{3}$ Vd. J. S. SILVA DIAS, A política cultural da época de D. João III. Coimbra, Universidade de Coimbra, 1969. Sobre os estudantes portugueses em universidades francesas, vd. L. MATOS, Les portugais en France au XVIe. Siècle, Coimbra, Por Ordem da Universidade, 1952; ID., Les Portugais à l'Université de Paris entre 1500 et 1550, Coimbra, Por Ordem da Universidade, 1950; J. V. SERRÃO, Portugueses nos estudo de Toulouse, Coimbra, Por Ordem da Universidade, 1954. Para o conhecimento de todo este ambiente cultural e de muitas particularidades da vida e obra dos nomes citados, e de muitos outros que fizeram do nosso Humanismo do Renascimento um momento de particular pujança e riqueza na nossa história cultural, constituem obra de referência imprescindivel os diversos estudos de A. COSTA RAMALHO, pioneiro, em Portugal, dos estudos sobre o Humanismo, e que se encontram, na sua larga maioria, reunidos nos volumes: Estudos sobre a época do Renascimento, Coimbra, Instituto de Alta Cultura - Centro de Estudos Clássicos e Humanísticos, 1969; Estudos sobre o século XVI, Paris, Fundação Calouste Gulbenkian - Centro Cultural Português, 
Sob a égide de uma nova pedagogia, o mesmo é dizer de uma nova forma de ver o mundo e os homens ou, talvez melhor, uma nova forma de ver o lugar dos homens no mundo, ou seja, sob os auspícios de uma nova Filosofia, eis como estes recentes protagonistas da cultura formaram a sua personalidade, antes de se abalançarem à tentativa, porventura vã, de transformarem hábitos, mentalidades, sociedade.

Essa nova pedagogia, se assim pode chamar-se, forjava-se no olhar atento e perscrutador dos clássicos, cuja redescoberta a segunda metade do século XV tinha definido como tarefa prioritária. Dos pergaminhos medievais iam renascendo Cícero, Virgílio, Ovídio, Horácio, Quintiliano, mas também Platão e todos aqueles que haviam sido, mais de quinze séculos antes, o berço daquela que viria a ser a cultura ocidental.

Não surpreende, por isso, que, entre as disciplinas que constituíam o centro da pedagogia renascentista e humanista e nas quais assentava, em especial, o curriculum universitário, ocupassem lugar privilegiado a Gramática, a Poética e a Retórica.

A primeira e a última eram já parte do triuium, isto é, do tríplice núcleo central da pedagogia dos finais da Idade Média, posto que a Retórica, em Portugal, estivesse reduzida a um quase total apagamento. ${ }^{4}$

Ora, Gramática e Retórica eram, igualmente, componentes essenciais da formação das elites na Antiguidade Clássica, particularmente na Roma antiga.

Foi com o Renascimento, entretanto, em larga medida graças à influência dos mestres humanistas formados nas escolas europeias ou dos estrangeiros que os acompanharam quando do seu regresso a Portugal, que a Retórica adquiriu importância efectiva e determinante na formação académica ministrada nas instituições de saber portuguesas.

Outras razões, porém, haverá para o peso crescente da Retórica no Portugal de Quinhentos e que com esta inquestionavelmente se cruzam:

1980; Para a história do Humanismo em Portugal, vol. I, Coimbra, Centro de Estudos Clássicos e Humanísticos, 1988, vol. II, Lisboa, Fundação Calouste Gulbenkian, Junta Nacional de Investigação Científica e Tecnológica, 1987, vols. III e IV, Lisboa, Imprensa Nacional - Casa da Moeda, 1998.

${ }^{4}$ A. P. CASTRO, Retórica e teorização literária em Portugal do Humanismo ao Classicismo. Coimbra, Centro de Estudos Românicos, 1973, 14. Parte das considerações que a seguir se desenvolvem muito devem à leitura do Cap. II desta obra, "Dos alvores do Humanismo ao limiar do Barroco" (pp. 13-81). Vd., ainda, deste mesmo autor, "Entre Cícero e Aristóteles: a retórica em Portugal, do Renascimento ao Barroco": A Retórica greco-latina e a sua perenidade. Actas do Congresso, vol. II, Coimbra, Instituto de Estudos Clássicos, 2000, 895-910. 
O Renascimento é, em toda a Europa, um tempo de ostentação, de fausto, de luxo. Ora, essa sociedade-espectáculo, se assim podemos chamar-lhe, encontrava na Retórica (a arte da palavra, por excelência), um primoroso instrumento de concretização dos seus desígnios.

Além disso, o Renascimento é uma época de profundas controvérsias, como é próprio de todos os tempos de viragem; em menos de um século, proliferaram violentas e dilacerantes contendas, algumas delas a raiar a intolerância, não raro de resultados dolorosos e, mesmo, trágicos. Tais controvérsias tinham, naturalmente, na Dialéctica o seu palco privilegiado, e esta possui na Retórica (a arte da palavra, repita-se, uma vez mais) um instrumento de eleição.

O saber retórico, é verdade, é transversal a todas as actividades onde a palavra ocupa lugar determinante, quer tenham subjacentes objectivos de natureza estética, quer visem outros efeitos; ele é importante na Filosofia, na prosa ficcional ou na Poética, por exemplo. Mas não é menos verdade que esse mesmo saber retórico se manifesta, de um modo muito peculiar, quando a palavra é dita de viva voz, ou seja, na Oratória.

É assim que a crescente importância da Retórica acaba por ser uma consequência lógica na evolução de uma sociedade que à vida em comum e à ostentação conferia lugar de tão grande relevo. Aí, como é bom de ver, a arte de bem falar torna-se determinante. $\mathrm{E}$ o bem falar, num tempo em que todos os modelos provinham de Roma ou da Grécia, equivalia a recuperar a eloquência clássica. $^{5}$

Desta forma, o mestre de Retórica, no Renascimento, acaba por preencher o ideal de uomo universale, em termos morais e políticos, e bem assim em termos literários e filosóficos. Por outras palavras, o orador torna-se uma espécie de paradigma do homem renascentista. ${ }^{6}$

Provam-no, desde logo, a quantidade e variedade de discursos em que é tão fértil o Renascimento, à maneira da civilização de Roma, que lhe servia de modelo:

Orações académicas, usualmente discursos em louvor de todas as disciplinas, pronunciadas, como hoje, na abertura do ano lectivo, na Universidade ou no Colégio das Artes.

${ }^{5}$ J. MONFASANI, "Humanism and Rhetoric": A. RABIL, Jr. (ed.), Renaissance Humanism: foundations, forms, and legacy, vol. 3, Humanism and the disciplines, Philadelphia, University of Pensilvania Press, 1988, 171. O trabalho de Monfasani, que faz uma excelente síntese da evolução da Retórica ao longo do Renascimento, ocupa as pp. 171-235.

${ }^{6}$ D. R. KELLEY, cit., p. 82. Cf., nesta obra, as páginas dedicadas à Ars Retorica (pp. 82-94). 
Orações de entrada, ou seja, discursos de saudação pronunciados por ocasião da chegada de um nobre às suas terras, quando delas tomava formalmente posse.

Orações de obediência, proferidas diante do Papa, seja quando mudava o Rei e o novo monarca enviava uma embaixada a Roma, para jurar lealdade e obediência ao Pontífice de Roma, seja quando este mudava e idêntico juramento era prestado ao novo Papa.

Discursos políticos ou militares, de vária índole, em Cortes, em cerimónias solenes, por ocasião da partida para grandes batalhas e em tantos outros acontecimentos que marcavam a faustosa sociedade renascentista.

E havia, ainda, a oratória sacra, que viria a ser aprofundada mais tarde, quase como uma disciplina autónoma, com a pedagogia dos Jesuítas.

O campo para o exercício da Ars retorica era, portanto, vasto e bem variado. E muitos foram aqueles que nele se destacaram. Alguns dos que enveredaram por esse caminho fizeram-no com tanto empenho que se tornaram, por assim dizer, "pregadores oficiais".

Um deles nasceu em Porto de Mós e veio a ser um dos mais prolixos oradores do século XVI. Trata-se de António Pinheiro, que foi bispo de Miranda e, mais tarde, de Leiria, mas que ficou conhecido menos pelo exercício do seu múnus episcopal em qualquer das duas dioceses do que pela sua actividade enquanto orador da Coroa.

Não é rara, no Renascimento, esta relação estreita entre os homens da hierarquia da Igreja, particularmente os que estavam investidos do poder episcopal, e a cultura. Em Portugal, vários foram os bispos que se destacaram como grandes figuras do humanismo renascentista: D. Frei Bartolomeu dos Mártires, bispo de Braga, humanista de vulto e que teve papel importantíssimo no Concílio de Trento; D. Miguel da Silva, bispo de Viseu, mais tarde Cardeal da Cúria romana, humanista e poeta; D. Jerónimo Osório, bispo do Algarve, um dos mais notáveis humanistas portugueses.

Leiria, neste aspecto, não é excepção: o primeiro bispo da diocese, D. Frei Brás de Barros, que era monge de S. Jerónimo, era um homem de letras, com obra publicada; ${ }^{7}$ D. Frei Gaspar do Casal, que lhe sucedeu, frade agostiniano, era doutor em Teologia, igualmente com obra publicada; ${ }^{8} \mathrm{e}$

${ }^{7}$ Escreveu: Espelho de perfeiçam em linguoa portuguesa, Coimbra, 1533; Livro das constituiçoens e costumes que se guardam em o Mosteiro de Sancta Cruz dos Cónegos Regrantes da Ordem de nosso Padre Sancto Agostinho, Coimbra, 1532.

${ }^{8}$ Publicou: Axiomata Christiana ex diuinis scripturis et sanctis patribus, cum ecclesiasticis, tum etiam scholasticis, Coimbra, 1550. 
D. António Pinheiro, de quem aqui se tratará mais detidamente. Reconheça-se, portanto, que a diocese de Leiria, logo após a sua criação, teve a dita de ver a Santa Sé designar para seus prelados homens de saber e cultura.

Avulta, entre todos, D. António Pinheiro, que ocupou o trono episcopal entre 1579 e 1582 .

Não consente a exiguidade do tempo, nem é esse o objectivo destas notas, um olhar minucioso e demorado sobre pormenores de natureza biográfica. Muitos se dedicaram já ao assunto, com larga cópia de documentos e informações e com prejuízo, convenhamos, do estudo da sua obra. ${ }^{9}$

Limitemo-nos, pois, no que à sua vida diz respeito, a uma breve súmula dos factos mais relevantes. Para tanto, a fonte mais segura continua a ser o autor anónimo de $O$ Couseiro, pese embora a cautela com que deve ser lido. A verdade é que a quase contemporaneidade entre o seu autor e o Bispo e orador the confere uma especial autoridade. Se tivermos em conta, de facto, que esse autor se refere ao ano de 1605 como "o meu tempo", ${ }^{10}$ o que significa que deverá ter nascido alguns anos antes, facilmente depreendemos que as fontes que utilizou foram, por certo, testemunhos de viva voz de contemporâneos do biografado.

Nasceu António Pinheiro em Porto de Mós, em ano incerto, à volta de 1510, filho de Pedro Vaz do Couto e de Leonor Álvares Pinheira ou Pinheiro.

A sua origem portomosense não sofre qualquer contestação, posto que alguns equivocos se tenham gerado a esse respeito. A verdade é que ele próprio, à boa maneira quinhentista, fez juntar a designação da naturalidade ao

${ }^{9}$ As breves notas biográficas que a seguir se apresentam foram coligidas em diversos estudiosos e nos escritos dispersos onde foram registando o resultado das suas pesquisas sobre António Pinheiro. Dado o carácter de síntese que se pretende para estas notas e porque, em boa parte dos casos, há informações que se repetem, nem sempre se dará aqui "o seu a seu dono", pelo que fica o pedido de desculpas aos respectivos autores. Foram as seguintes as fontes utilizadas: $O$ Couseiro ou memórias do bispado de Leiria, Braga, Typographia Lusitana, 1868 (fac-simile, Leiria, 1980); F. M. ALVES, Memorias archeologico-historicas do distrito de Bragança, Tomo II, Porto, Typographia a Vapor da Empreza Guedes, 1910, 14-15; A. ZÚQUETE, Leiria, subsidios para a história da sua diocese, Leiria, Gráfica de Leiria, 1943, 155-166; ID., "Problemas históricos que se esclarecem: a sepultura de D. António Pinheiro; o mistério da chamada «sepultura grande» da Sé": $A$ Voz do Domingo, 7 de Setembro de 1947; A. G. TINOCO, Dicionário dos autores do distrito de Leiria, Leiria, Edição da Assembleia Distrital, 1979 (reed. Leiria, Magno, 2004, coord. ACÁCIO SOUSA, A. B. VINAGRE e C. NOBRE); ALFREDO DE MATOS, D. António Pinheiro, ed. autor, s/l, s/d.

${ }^{10} \mathrm{O}$ Couseiro, p. 13. 
nome, sendo conhecido, nos meios académicos e humanistas, como "António Pinheiro de Porto de Mós" ou, em latim, Antonius Pinarius Portodemaeus ou Antonius Pinus Portodemaeus. É assim mesmo que assina a carta-dedicatória a Diogo de Gouveia dos seus In tertium M. Fabii Quintiliani librum luculentissimi commentarii. " E é também com esse nome que se lhe referem outros autores, por exemplo o poeta Diogo Pires que, na sua carta a Paulo Jóvio, em 1547 , o cita entre os mais destacados homens de letras portugueses. ${ }^{12}$

Beneficiário de uma das bolsas da Coroa, estudou em Paris, na Sorbonne e no Colégio de Santa Bárbara, onde há registos com o seu nome em 1533-34, se é que um Antonius Pinus, em 1527, não era já a mesma pessoa, por equívoco designada Eburensis. ${ }^{13}$

Aí terá obtido o grau de doutor, possivelmente em Teologia, se bem que não se conheçam até agora documentos comprovativos. Seja como for, os seus méritos enquanto aluno justificaram que, no mesmo Colégio de Santa Bárbara, viesse, logo depois, a ensinar Retórica, disciplina em que se notabilizou pelas suas lições sobre o Livro III das Institutiones Oratoriae de Quintiliano, que veio, mais tarde, a editar. ${ }^{14}$

Cerca de 1540, D. João III envia a Paris Frei André da Ínsua, com o objectivo de recrutar, entre os mestres portugueses ali radicados, "uma pessoa mui douta em latim, para ensinar os moços fidalgos". ${ }^{15}$ A escolha do emissário do rei recaiu sobre António Pinheiro, que retornou, por isso, a Portugal, onde

"Publicada por LUÍS DE MATOS, Les Portugais à l'Université de Paris entre 1500 et 1550 , cit., 147-150.

12 Vd. CARLOS A. ANDRÉ, Um judeu no desterro: Diogo Pires e a memória de Portugal, Coimbra, Instituto Nacional de Investigação Científica, Centro de Estudos Clássicos e Humanísticos da Universidade de Coimbra, 1992, 107-108; a carta a Paulo Jóvio é publicada na íntegra e traduzida nas pp. 159-174.

${ }^{13}$ LUÍS DE MATOS, Les Portugais à l'Université de Paris entre 1500 et 1550, cit., 72 e 123. ALFREDO DE MATOS cita várias outras referências da passagem por Paris, coligidas, nomeadamente, em Quicherat, que escreveu a história do Colégio de Santa Bárbara.

14 Commentarii et annotationes in Marcum Fabium Quintilianum de Institutione Oratoria cum iisdem institutionibus, Veneza, 1567 e Paris, 1569. Barbosa Machado refere uma publicação anterior, de Paris, 1538, dos comentários ao terceiro livro de Quintiliano, que constituíram o objecto das suas lições em Santa Bárbara. Dessa obra, a que acima se faz referência e cuja carta dedicatória a Diogo de Gouveia foi publicada por Luís de Matos (vd. supra, n. 10), não se conhece, no entanto, qualquer exemplar.

${ }^{15}$ LUÍS DE MATOS, Les Portugais à l'Université de Paris entre 1500 et 1550 , cit., 72 . 
se encontrava já em 1541, a exercer funções como preceptor de filhos da nobreza, até que o Rei lhe confiou a educação do Príncipe D. João, o pai de D. Sebastião.

Assim faz o Doutor António Pinheiro a sua entrada na Corte, onde veio progressivamente adquirindo prestígio e simpatias, nomeadamente junto da família real. Essa relação estreita com a Coroa não mais se extinguirá, não obstante as mudanças que no trono português se vieram verificando na segunda metade do século.

$\mathrm{O}$ início não terá sido fácil. Acabado de chegar de Paris, conheceu problemas de adaptação à nova vida no Paço.

Estávamos longe, ainda, do tempo em que o seu peso e influência na Corte e junto da família real seriam indiscutíveis. O ânimo vacilou-lhe. Sentiu a solidão, julgava-se à mercê de ódios, intrigas e invejas. Isso espelha bem em texto dirigido ao Rei, na carta que antecede a tradução do Panegírico de Trajano, de Plínio, levada a efeito em 1541.

Moveu-o, desde logo, afiança, o ócio em que vivia: "via-me tam em nada occupado". Mas impeliu-o também a abalançar-se à tradução o clima de inveja, intriga e mediocridade que na corte se respirava e de que se considerava, em larga medida, vítima:

Via-me na Corte, onde minhas obras haviam de ser sentenciadas per juizes sem suspeita de muito saber, mal informados das letras, traçadores de famas alheas, demarquadores de medranças, limitadores de honrras, encurtadores de binignidade de V. A., e bem se ho nam fossem do Real patrimonio. Via-me finalmente com ditos de duas figuras, requerente e estudiozo; dos quaes hum me representaua a fame, outro a fama. Aguça a necessidade os engenhos pera artes servijs, botahos pera as liberaes; may he dos mechanicos, madrasta dos letrados, e estando ja demovido a dar a minha vida por esquecida e passar aa bandeira dos que trocaram o esplendor do nome pollo encuberto gosto, nem quiseram comprar a gloria da posteridade com serem conhecidos dos da sua idade... ${ }^{16}$

Este desencanto foi, porém, efémero e de pouca dura. Podia mais o ânimo do ainda jovem preceptor do que um ocasional sentimento de frustração. E, concluída a tradução, emoldurada pelo panegírico do Rei, em cuja personalidade via, com gosto, tudo quanto em Trajano "é pintado", continuou, ao que parece, a merecer as graças de Rei e Rainha.

${ }^{16}$ Trelladaçam do Panigyrico de Plínio o mais moço, dito no Senado em louuor de Trajano, em nossa vulgar lingoagem. Publicado no Tomo II da Colleçam das obras portuguezas do sábio Bispo de Miranda e Leiria D. António Pinheiro.... Feita por Bento Joze de Souza Farinha, Lisboa, Na Of. de Joze da Silva Nazareth, 1785. O passo citado vem a pp. 3-4. 
A sua escolha para cronista-mor do reino acaba por ser, pois, uma evolução natural. Há quem afiance que the foi confiado o encargo de prosseguir a Crónica de D. Manuel, iniciada por Rui de Pina e que o seu filho, Fernão de Pina, preso às ordens da Inquisição, não logrou continuar. Aos que põem este encargo em dúvida parece opor-se o testemunho a este respeito de Damião de Góis. ${ }^{17}$

A crónica, todavia, que com mais insistência lhe foi solicitada foi a de D. João III. A correspondência trocada entre o Doutor António Pinheiro e a rainha-viúva é bem elucidativa. Directamente ou por interpostos mensageiros, D. Catarina apelava repetidamente a que pusesse mãos à obra e a levasse a bom termo. Seja por falta de elementos, seja porque os que lhe iam disponibilizando os considerava insuficientes, seja, enfim, porque outro era o rumo que pretendia dar à sua vida e outros os objectivos que visava, o certo é que o futuro prelado ia retardando a satisfação do pedido.

Chegou, mesmo, a Rainha a mostrar, com o facto, algum enfado e desconforto, por carta que lhe remeteu em 2 de Agosto de 1552, onde, entre outras coisas, lhe diz: pesoume muito que o tempo que nisto ouvereis de empregar fosse necessario gastallo em ver que os papeis que de ca forão não servião pera vosso intento... ${ }^{18}$

Nem mesmo assim o doutor portomosense levou por diante o empreendimento. Quer tenha ou não sido nomeado cronista-mor do reino, o que é duvidoso, quer lhe tenha sido confiado, tão-somente, o encargo de escrever a crónica do reinado de D. João III, o que é mais provável, esse foi intento que nunca chegou a concretizar. ${ }^{19}$

${ }^{17}$ DAMIÃO DE GÓIS, Crónica de D. Manuel, $4^{\mathrm{a}}$ parte, cap. 37. Ainda que o teste-munho de Góis não seja inequívoco e, portanto, não possa servir de prova de que o encargo havia sido confiado a António Pinheiro, permite deduzir, no mínimo, que chegou a existir essa intenção. Cf. A. ZÚQUETE, Leiria, subsidios para a história da sua diocese, cit., 157-158.

18 Apud SOUSA VITERBO, Damião de Goes e D. António Pinheiro: apontamentos para a biographia do Chronista de D. Manuel, Coimbra, Imprensa da Universidade, 1895, 29.

${ }^{19}$ Sobre a controvérsia que envolve a alegada nomeação de António Pinheiro como cronista-mor do reino, aceite por uns e desmentida por outros, e o modo como acabou por não se desempenhar do encargo de escrever a crónica de D. João III, vd. J. V. SERRÃO, A historiografia portuguesa, doutrina e critica, Vol. I, Séculos XII-XVI, Lisboa, Editorial Verbo, 1972, 186-196, com grande abundância de documentos e bibliografia. Vd., ainda: SOUSA VITERBO, cit. com transcrição de parte da correspondência trocada entre a Rainha e o humanista; A. ZÚQUETE, Leiria, subsidios para a história da sua diocese, cit., 157-158; Alfredo MATOS, cit., 14-16. 
Quando, entretanto, foi necessário confiar a alguém a educação do pequeno D. Sebastião, a escolha recaiu sobre o jesuíta Luís Gonçalves da Câmara. António Pinheiro ter-se-á sentido despeitado e terá feito sentir à Rainha o seu desagrado por ter sido preterido. ${ }^{20}$

Seja como for, a verdade é que este episódio não diminuiu os seus méritos aos olhos da Casa Real, e ele permaneceu como pregador régio, encarregado de proferir os discursos da praxe nas mais solenes ocasiões, como adiante se dirá.

Em 1565, encontramo-lo em Coimbra, nomeado Visitador e Reformador da Universidade. Aí o recebem os Doutores em claustro pleno, em 19 de Fevereiro, para o juramento segundo a forma tridentina. ${ }^{21}$

Aspirava, todavia, o pregador a mais altas honrarias na hierarquia da Igreja. Decerto por influência de D. Catarina, cujos favores sempre mereceu, e, talvez, em jeito de compensação pelo facto de lhe não ter sido confiada a educação do futuro rei, fora nomeado bispo de Miranda, provavelmente em 1564; nessa função o encontramos já em 1566.

Não permaneceu nas terras deste seu episcopado a tempo pleno. Manteve, de facto, a sua actividade intensa como pregador régio e orador oficial da Coroa, o que o terá mantido afastado por temporadas razoáveis da diocese transmontana. Talvez por isso, porque dos seus afazeres episcopais não curava tanto quanto o dever the impunha, o seu mandato ficou assinalado por alguns problemas que deixou insolúveis; entre eles, o não cumprimento da decisão do Concilio de Trento no que diz respeito à edificação de seminários para formação do clero; apesar de muito instado a cumprir tais disposições, o bispo mirandino viria a deixar a diocese sem o fazer. ${ }^{22}$

Verdade seja que as terras de Bragança e Miranda não logravam, de modo algum, satisfazer a personalidade de D. António Pinheiro; tratava-se, por um lado, de uma diocese, por assim dizer, de segunda, meio perdida nos confins do território e, por isso, de muito reduzida importância; a estadia ali representava, por outro lado, uma espécie de exílio, um longo afastamento da corte, sem a qual a sua personalidade tinha dificuldade em sobreviver. António Pinheiro era, de há muito, um homem de corte; esse era o seu espaço natural; difícil se lhe tornava, pois, viver à margem dela, ainda que por razão tão nobre como o desempenho das honrosas funções episcopais.

Ambicionava, por isso, uma diocese que fosse mais consentânea com esse duplo desejo: ser titular de um cargo de maior prestígio e ficar-se por mais

${ }^{20}$ J. V. SERRÃO, cit., 190; A. ZÚQUETE, Leiria, subsídios para a história da sua diocese, cit., 159 .

${ }^{21}$ Apud F. M. ALVES, cit., 16.

${ }^{22}$ ALFREDO MATOS, cit., 17-23. 
perto de Lisboa e do Paço. A ocasião surgiu em 1579, quando, com a vacatura da diocese de Coimbra, o bispo leiriense D. Frei Gaspar do Casal foi designado seu titular, deixando livre a diocese de Leiria.

Aí veio a tomar posse em 1579 e aí se manteve até 1582 , ano em que faleceu, entre finais de Outubro e começos de Novembro.

Mas nem por ser mais perto da capital Leiria conseguiu deter em suas terras este seu bispo. Era, repita-se, homem de corte e o pregador ali preferido. O país vivia, além disso, anos de profunda convulsão: a morte de D. Sebastião em Alcácer Quibir, o reinado quase sem esperança do Cardeal D. Henrique, as ambições ao trono por parte do Rei de Espanha. Homem acostumado aos jogos de poder, D. António Pinheiro não quis manter-se afastado de todas essas movimentações, antes quis nelas ser parte integrante e activa.

Delegou, por isso, como hoje se diria, parte das suas funções no seu arcediago, Gonçalo Aires de Sá. ${ }^{23}$

Faleceu, como se dissse, em 1582, em finais de Outubro ou começos de Novembro, já que o cabido lhe fez os ofícios a 8,9 e 10 de Novembro, e a Sé havia sido declarada vacante a 30 de Outubro. ${ }^{24}$ Foi sepultado, ao que tudo leva a crer, na Sé Catedral de Leiria, na chamada "sepultura grande" ou, pelo menos, para ali foi trasladado, conforme assegura $O$ Couseiro. A ideia de que possa ter sido sepultado em Porto de Mós carece de qualquer fundamento. Sem pretender reeditar aqui a polémica que a esse respeito se instalou, creio que são elucidativos os argumentos de Afonso Zúquete. ${ }^{25}$

Todos estes elementos de ordem biográfica se encontram coligidos por vários autores que se dedicaram largamente a tentar deslindar o fio da meada que é a vida do prelado leiriense. Afadigados, porém, os estudiosos nessa procura, descuraram aquilo que é, seguramente, o mais importante, ou seja, a sua obra. Ora, António Pinheiro é bem mais do que um simples roteiro biográfico; não se limitou, aliás, a presenciar a grande maioria dos momentos que marcam as duas décadas dramáticas que antecedem 1580; foi activo e interveniente em alguns desses momentos. Não era, apenas, o pregador régio, o orador de circunstância; foi, não raro, o porta-voz daqueles a quem de perto servia. Foi um humanista, no mais autêntico sentido da palavra: porque se dedicou ao estudo das humaniores litterae e as cultivou, desde os tempos de

${ }^{23}$ A. ZÚQUETE. Leiria, subsídios para a história da sua diocese, cit., 163.

${ }^{24}$ O Couseiro, 189.

${ }^{25}$ A. ZÚQUETE, "Problemas históricos que se esclarecem", cit. A questão já fora tratada por este mesmo autor em Leiria, subsidios para a história da sua diocese, cit., 164-165. Vd., também, ALFREDO MATOS, cit., 55-58. 
Santa Bárbara; porque exerceu uma acção cívica, na pedagogia, mas também na actividade política.

A primeira obra que dele se conhece resulta dos estudos de Retórica em Paris, assim prenunciando aquele que viria a ser o seu percurso, a oratória.

Preparou, em 1538, na capital francesa, uma edição do terceiro livro das Institutiones de Quintiliano: In tertium M. Fabii Quintiliani librum luculentissimi commentarii, que dedicou a Diogo de Gouveia, o qual ali dirigia, então, o Colégio de Santa Bárbara. Mas, no momento de dar o seu trabalho à estampa, foi mais longe no seu intento e editou a obra de Quintiliano completa: Commentarii et annotationes in Marcum Fabium Quintilianum de Institutione Oratoria cum iisdem institutionibus, que veio a lume em Veneza, em 1567, e em Paris, em $1569 .^{26}$

Foi escassa, no entanto, no que respeita aos estudos de Retórica, entre nós ou além-fronteiras, a influência dos Comentários do humanista à obra de Quintiliano, a ajuizar pelas referências que lhe são feitas por quantos a essa disciplina se dedicaram. ${ }^{27}$

Acreditava, no entanto, o jovem humanista que as velhas disciplinas do triuium tinham um papel importante a desempenhar na educação. Terá sido por isso que preparou uma edição de exercícios de Gramática - Grammaticae exercitationes - que dedicou à Infanta D. Maria. ${ }^{28}$

$\mathrm{O}$ texto, que não chegou a ser publicado e cujo manuscrito se encontra na Biblioteca Nacional de Madrid, contém uma carta-dedicatória à Infanta, onde a estimula ao estudo das letras, das humanidades e da Gramática. E, acrescenta, não deve ser a sua natureza feminina a impor-lhe qualquer travão a um tal projecto,

Praesertim cum eruditionis laude illustres feminae excelluerint, nec in honorem modo sexus sed supra uirilem etiam admirationem, nomen in litteris sint plurimae consecutae.

... em especial quando é certo que muitas mulheres ilustres se tornaram notáveis graças à sua erudição; e não foi apenas para honra do seu sexo que alcançaram nome nas letras, mas, mais ainda, vieram a suscitar admiração por parte dos homens. ${ }^{29}$

${ }^{26}$ Venetia, apud Hyeronimum Scotum, 1567; Parisiis, apud Vascosanum, 1569.

${ }^{27}$ A. P. CASTRO, cit., 51-52.

${ }^{28}$ Vd. A. G. IGLESIAS, "Una lección de latín en el siglo XVI: el ms. 6498 de la Biblioteca Nacional": Revista de Archivos, Bibliotecas y Museos 55.1 (1949) $5-55$, com estudo e edição do manuscrito.

${ }^{29}$ Ibidem, 14. 
A sua apetência pelas letras clássicas levou-o, ainda, a traduzir uma carta de Cícero a seu irmão, tradução essa que dedicou à mesma Infanta D. Maria. A tradução, de resto, parece ter sido uma actividade que especialmente lhe agradava. O principal resultado desse ofício de tradutor foi, em 1541, o Panegírico de Trajano, de Plínio, que dedicou ao próprio Rei e a que já atrás foi feita referência.

É, porém, na sua obra oratória, nos seus discursos e pregações, que melhor se evidencia o seu pensamento; tais discursos são, além disso, a melhor prova da importância da sua acção na emaranhada política portuguesa do terceiro quartel do século XVI.

Ao contrário do que sucedeu com muitos humanistas seus contemporâneos, que fizeram do Latim a sua língua de eleição, seja em escritos, seja na oratória, os discursos e pregações de António Pinheiro, pelo menos os que nos chegaram, foram pronunciados e editados em Português.

Tais textos são bem o reflexo da longa aprendizagem da Retórica na academia parisiense. Não será este o lugar para apreciar detidamente as suas qualidades de orador. Vale a pena, em todo o caso, olhar um ou outro exemplo das suas virtualidades retóricas.

Observe-se um fragmento do discurso que pronunciou, em 1561, diante de D. Catarina, a Rainha viúva de D. João III, quando a ela se dirigiu, em nome do povo de Lisboa, para que nam largasse a regencia do reyno. ${ }^{30}$ Falou com desassombro diante da rainha regente, com sólidos argumentos que pretendiam ser a antevisão da degradação do poder, no caso de ela levar por diante o seu intento. Não se coíbe de referir os desmandos que já então caracterizavam o clima político e social da capital; as suas palavras adquirem uma força especial por força do peso do código retórico:

Contudo sam tantas e tam grandes as obrigaçoens, que V. A. tem aos reger e governar, ate os entregar pacificos a el Rey nosso senhor seu neto, que comparadas as couzas por que se V. A. move, para desistir da governança delles, com as que obrigam a perseverança nella, parece geralmente a todos que no que $V$. A. diz, que faz pera descargo de sua consciência, a encarrega: e no que escolhe pera seguridade de sua salvaçam, a põem em perigo; e no que lhe parece que serve a nosso Senhor, o deserve. Por que como elle seja o author da paz e conservador da ordem e pacificador de escândalos, parece que he com grande escândalo e offensa sua e de sua divina

${ }^{30}$ Falla que fez à Raynha D. Catherina em nome do povo de Lisboa para que nam largasse a regência do Reyno no anno de 1561. Publicado no Tomo I da Colleçam das obras portuguezas do sábio Bispo de Miranda e Leiria D. António Pinheiro.... Feita por Bento Joze de Souza Farinha, Lisboa, Na Of. de Joze da Silva Nazareth, 1785, 197-201. 
bondade, obra que daa tanta occasiam a desordens e escandalos e outras novidades, a que estam sogeitas as alteraçòes e mudanças de regimentos, e que deve $V$. A. de temer muito sua justa indinaçam; porque com fazer mercê a todos, as pode atalhar e remedear. E poes da perseverança de V. A. na governança destes Reynos tantos bens se conservam e tantos males se impedem, parece claramente que a continuaçam de $V$. A. no regimento delles he obra a Nosso Senhor muito aceita e tanto de maior merecimento quanto he mayor a charidade de que procede e o fruito della he maes geral e maes commum a todos. ${ }^{31}$

Ou atente-se neste outro exemplo, porventura mais elucidativo, do discurso pronunciado por ocasião da trasladação dos restos mortais de D. Manuel para os Jerónimos e publicado, depois, em $1551 .^{32}$ Refere-se o orador ao Mosteiro dos Jerónimos, justamente o lugar para onde serão trasladados os ossos do Rei e da Rainha. Neste caso, o preciosismo retórico é inequívoco:

A fim de se ver que o lugar donde elle despidio a armada primeira, que daqui mandou a este descubrimento, e onde ella tornou estaa dâdo testemunho de sua deuação; $e$ sendo hum tropheo dos triumphos doriente, e da ampliação grande de nossa sancta fee catholica, nos regnos delle. Aqui escolheo sua sepultura, pera daqui lançar a bênção aos que prosseguião o que elle começaua: e onde os orientaes que nas naos viessem, soubessem q fora homem o de quem se elles espantarão e temeram, como se fora de Deos. Aqui se rogasse pella prosperidade dos que partissem; aqui se dessem graças polla saude dos que tornassem; aqui se enterrassem os naufragos lançados a costa; aqui se agasalhassem os pobres mareantes; aqui achassem remedio pera os corpos, refrigerio pera as almas, daqui se proueessem do spiritual, aqui achassem suprimento pera o temporal, aqui ouue por bem que se visse o em que acaba tudo. ${ }^{33}$

Como acima se disse, António Pinheiro nunca terá chegado verdadeiramente a deitar mãos à obra de escrever a Cónica de D. Manuel, se é que alguma vez recebeu essa incumbência, o que é por demais duvidoso. Se o tivesse feito, porém, não seria menos panegírico em relação ao reinado do "Venturoso", a avaliar pelo modo como, neste sermão da trasladação dos seus restos mortais, se refere à sua obra.

${ }^{31}$ Pp. 197-198.

${ }^{32}$ Summario da pregaçam funebre que o Doutor António Pinheiro, pregador del Rey N. S. fez por seu mandado: no dia da Trasladação dos ossos dos muito altos \& muito poderosos principes elRey dõ Manuel seu pay, \& a Rainha dona Maria sua Mãy de louuada memoria, derigido aa muyto alta \& muyto poderosa Rainha dona Catherina N. S. Impresso em Lixbõa em casa de Germão Galhard, Imprimidor del Rey N. S. 1551.

${ }^{33}$ Fl. xvij e v ${ }^{\circ}$. 
Um dos aspectos do elogio de D. Manuel revela, curiosamente, o forte pendor anti-judaico do pensamento do pregador, porventura ditado pela sua proximidade em relação à Rainha, cujo ódio ao povo hebraico é conhecido. A perseguição contra os Judeus, desencadeada por D. João III, muito ficou a dever à influência dela. António Pinheiro, no entanto, prefere recuar, com inteira razão, convenhamos, e situar no reinado de D. Manuel a origem da hostilidade política contra os Judeus. As palavras são elucidativas:

Se restaurar a Pascoa judaica em tempo que a obseruãncia della hera meritoria foy reputado a Osias em grande seruiço, quem não vee que o fez mayor a Deos el Rey dom Manuel, em tolhela no tempo em que a guarda della era já perniciosa e mortal? Senam que quãto mays se offende a Deos cõ os males que fazemos, que com os beens que deixamos de fazer, tãto mays acepto the seria tolher o com que se elle offendia que restituir o em que se antes não seruia. ${ }^{34}$

A dado passo, enumera, com algum pormenor, aquilo que o mundo ficou a dever a D. Manuel:

$\mathrm{O}$ conhecimento do mundo, antes de mais, com o desenvolvimento da cosmografia. É a ele que atribui um decisivo estímulo ao desenvolvimento da "sciencia da esphera", por meio da qual se corrigiram muitos erros que até então andavam propalados:

desengano dos erros dos antigos: verse q o habitado he o mais e que nas zonas que tinham por inhabitaueis e desertas se viue temperada e suauemente, saberse a ladeza e cõpridão do mundo; serem as tauoas certas, o sitio dos lugares verdadeiro; a graduação puntual, emmendarensse os nomes; côformarensse os erros cõ a experiência; tratarsse mais o mundo; andarsse pello mar sem medo, auersse por fácil o que antes se não cria; deue a vida a este Rey por que per sua industria se nos comunicaram muitos remédios pera ella. ${ }^{35}$

Refira-se que esta convicção de que a D. Manuel e à sua política se ficou a dever a mais importante parte no sucesso dos Descobrimentos é partilhada com muitos contemporâneos. Assim pensa igualmente Diogo do Couto, por exemplo, que, no Soldado Prático, contrapõe vezes sem conta aqueles tempos austeros e gloriosos aos do presente.

O bispo leiriense, aliás, nesta mesma senda, não obstante a permanente "colagem" à corte e ao Rei, fosse ele qual fosse, deixa também escapar alguns laivos de desencanto perante a situação que no seu tempo começava a viver-se, com inequívocas marcas de degradação.

\footnotetext{
${ }^{34}$ Fl. xii vo.

${ }^{35} \mathrm{Fl}$. xviij vo.
} 
Na oração que pronunciou nas Cortes de Lisboa, ${ }^{36}$ nos Paços da Ribeira, as primeiras convocadas por D. Sebastião, não se coíbe de afirmar isso mesmo: que as Cortes foram convocadas para pôr fim a desmandos e excessos que lavravam no Reino. São estes, portanto, os objectivos da convocatória régia:

... e que resulta della nam somente o remédio das necessidades. E couzas, a que per mandado de S. Alteza sois chamados; mas tambem dos abuzos, excessos, superfluidades, delicias, corrupções dos bons, e antigos costumes, com a observancia dos quaes estes Reynos floreceram sempre e prosperaram; e por cujo esquecimento vivem carregados e opprimidos de continuas necessidades, e trabalhos: se se pode dizer, que vive o Reyno, que como paralitico em seu leito dura há tantos annos, sem dos beneficios, que lhe foram applicados, sentir saudavel e constante melhoria. ${ }^{37}$

A metáfora do paralítico prostrado no leito, para representar o reino degradado, surge na sequência do prolongado recurso, nos parágrafos que antecedem este mesmo passo, à comparação do reino a um corpo, cuja cabeça é o Rei. Neste aspecto, o pregador mais não faz do que recorrer a uma metáfora clássica, bem usual no Renascimento e que, entre nós, fora largamente adoptada, por exemplo, por Sá de Miranda.

É uma imagem, como diz, herdada dos "antigos sábios":

... pelo qual o Rey, em quem a Republica transferiu todo o poder, e authoridade de reger, e mandar, he comparado a cabeça; e aos membros inferiores os vassallos, que como subditos estam obrigados a servir, e obedecer. ${ }^{38}$

E, mais adiante:

Sol he o Rey em seu Reyno; de seus rayos a Republica, como a Lua, recebe luz, e resplendor, e esclarece sua fermosura; e em todas suas partes recebe hũa suave e natural quentura, com que prospera e persevera em seu vigor. Olho he o Rey, que pera seus vassallos poderem repouzar quietos, sempre vela. $O$ que he a alma no corpo composto de quatro elementos, he o Rey no Reyno composto de tres Estados. ${ }^{39}$

${ }^{36}$ Oraçam que fez e disse o Doctor Antonio Pinheyro na salla dos Paços da Ribeyra, nas primeyras cortes que fez o muyto alto e muyto poderozo Rey D. Sebastiam o I. Nosso Senhor, governando seus reynos e senhorios, a muyto alta e muyto poderoza Raynha Dona Catherina sua avo Nossa Senhora. Publicada no Tomo I da Colleçam das obras portuguezas do sábio Bispo de Miranda e Leiria D. António Pinheiro.... Feita por Bento Joze de Souza Farinha, Lisboa, Na Of. de Joze da Silva Nazareth, 1785, 182-196.
${ }^{37}$ P. 186.
${ }^{38}$ P. 182.
${ }^{39}$ P. 183. 
E transita, subtilmente, para uma nova metáfora, que compara o reino à colmeia e o Rei à abelha-rainha, porventura colhida nas Geórgicas de Virgílio:

A abelha, que sem ter aguilham com que lastime, prezide aas outras, semelhança he do Rey, cujo sceptro ha de ter severidade sem rigor; authoridade com clemencia... ${ }^{40}$

Detém-se, depois, largamente, na apreciação do papel do Rei enquanto cabeça do corpo que é o reino:

.... Porque a cabeça natural, que he a sua imagem, e figura o que mais tem que os outros membros, que he ser assento da razam, e da mayor e melhor parte dos sentidos, tudo converte em beneficio dos membros que a ella sam sogeitos. Nella vem os subditos e vassallos a obrigaçam, que tem de aliviar o pezo das necessidades $e$ trabalhos, que seu Rey padece, pois sam membros a que o Rey como cabeça daa politico movimento e sentido. ${ }^{41}$

Em resumo, a pátria, entendida como o colectivo dos cidadãos juntamente com o território que habitam, é o corpo; o Rei é desse corpo a cabeça, que a todos governa com esclarecimento e razão. Acontece, porém, que, como se viu, o corpo estava doente, padecia de grave enfermidade, fruto de desmandos e excessos dos seus membros. ${ }^{42}$

Ter esta nota presente ajuda a compreender a atitude do prelado leiriense, após a morte de D. Sebastião e durante o curto reinado do Cardeal D. Henrique.

Porta-voz do cardeal-Rei nas Cortes de Almeirim, em 1580, foi a ele que coube, em nome do monarca, abrir a reunião, em 11 de Janeiro, com um breve discurso de saudação aos representantes dos Estados. ${ }^{43} \mathrm{O}$ discurso foi pronunciado assumidamente em nome de D. Henrique; mas é visível o dedo do

\footnotetext{
${ }^{40}$ P. 183.

${ }^{41}$ P. 184.

${ }^{42}$ Sobre este passo do discurso de António Pinheiro, vd. NAIR N. C.
} SOARES, O príncipe ideal no século XVI e a obra de D. Jerónimo Osório, Coimbra, Instituto Nacional de Investigação Científica, 1994, 175-178. Nesse estudo, aliás, a autora refere-se amiúde ao bispo de Leiria e a sua obra, que analisa, em profundidade, e transcreve passos diversos dos seus textos, elaborados no âmbito do magistério de príncipes, a que tanto se dedicou.

${ }^{43}$ Falla do Bispo D. Antonio Pinheyro nas Cortes del Rey D. Henrique em Almeyrim. A 11 de Janeiro de 1580. Publicado no Tomo I da Colleçam das obras portuguezas do sábio Bispo de Miranda e Leiria D. António Pinheiro.... Feita por Bento Joze de Souza Farinha, Lisboa, Na Of. de Joze da Silva Nazareth, 1785, 202-205. 
Bispo na escolha das palavras, que apontavam para uma indefinição na atribuição do trono. Seja como for, nessas palavras, nem o Cardeal-Rei nem o Bispo seu porta-voz foram além dos votos indispensáveis ao bom êxito da missão.

Um ano depois, em 16 de Abril de 1581, reuniam em Tomar, uma vez mais, as Cortes. Nesse momento, já não restavam dúvidas ou, pelo menos, António Pinheiro não deu delas conta: o objectivo era aclamar Filipe II como rei de Portugal. E o bispo leiriense que, a despeito das mudanças políticas, manteve o estatuto de pregador régio, colocou a sua força argumentativa e persuasória ao serviço desse intento. ${ }^{44}$

Aflorou subtilmente a legitimidade dinástica de Filipe II, neto de D. Manuel, filho da sua filha, a Imperatriz Isabel, tio do malogrado D. Sebastião, parente mais chegado, legitimo varam mayor em idade del Rey D. Henrique, que sancta gloria haja, por cujo fallecimento e legitima successam ficou logo verdadeiro Rey e natural Senhor destes Reynos. ${ }^{45}$

Mas vislumbra uma segunda legitimidade, se assim pode dizer-se, na pretensão do rei de Espanha à coroa portuguesa; di-lo o pregador, conquanto que de forma subtil - restabelecer a ordem no país, introduzir a justiça, impedir a degradação; o rei espanhol, de facto,

vendo os movimentos e alteraçòes com que sua justiça e a paz destes Reynos se perturbava, em grande perjuizo e manifesta ruyna delles; e querendo como Rey e Senhor delles, com a brevidade que convinha remediar as oppressoens e tyramnias, que seus bons e leaes vassallos e tam fieis padeceram, os veyo por sy reger e governar, consolar e honrar com sua real presença, entrando nelles com o poder e authoridade necessária pera pacificar as inquietações delles e para ordenar e prover em tudo o que entendesse que cumpria pera conservaçam da paz, justiça e bem commum delles. ${ }^{46}$

Todo o discurso, aliás breve, visa um objectivo simples: provado que fica - pelo menos é esse o pressuposto - que Filipe é o legítimo herdeiro do trono português, estimular os representantes dos estados nas Cortes a aclamarem-no como Rei.

${ }^{44}$ Falla do Bispo D. Antonio Pinheyro no acto do alevantamento de S. Magestade nas Cortes de Thomar. Em 16 de Abril de 1581. Publicado no Tomo I da Colleçam das obras portuguezas do sábio Bispo de Miranda e Leiria D. António Pinheiro.... Feita por Bento Joze de Souza Farinha, Lisboa, Na Of. de Joze da Silva Nazareth, 1785, 206-209.

${ }^{45}$ P. 206.

${ }^{46}$ P. 207. 
Assim sucedeu. E, quatro dias depois, em 20 de Abril, volta D. António Pinheiro a discursar perante as Cortes, não já para apelar à aclamação do monarca, mas para incentivar a uma atitude colaborante para com ele. ${ }^{47}$ Uma vez mais, o artificiosismo retórico e a argúcia argumentativa do orador são colocados ao serviço da Coroa, neste caso do pretendente espanhol ao trono português. Esgotada, com efeito, toda a argumentação, recorre a um raciocínio particularmente perverso, que conjuga a evocação de sentimentos de gratidão com uma velada ameaça de represálias. Assim se podem entender as discretas alusões às grandes mercês e benefficios que lhes dezeja fazer, no amplíssimo e benignissimo perdam que mandou publicar antes destas Cortes; remitindo as penas aos que induzidos, enganados ou compelidos offenderam a paz publica, perturbaram sua justíssima posse da legitima successam delles, como da Carta do perdam, que com geral consolaçam de todolos Estados se ouviu. ${ }^{48}$

Fiel a esta dedicação ao novo poder, D. António Pinheiro voltará a discursar, uma vez mais, em Cortes, a 23 de Abril de $1587 .{ }^{49}$ Pretendia-se, então, que fosse aclamado o Infante D. Diogo, filho de Filipe II de Espanha, como herdeiro do trono português, como era de tradição. O discurso, agora, não precisava de ser tão veemente; o poder estava instituído e a legitimidade de D. Diogo, depois de seu pai ser Rei de Portugal, era inquestionável. Tratava-se, portanto, de cumprir uma tradição. Assim se fez.

Todo este fervor de D. António Pinheiro em favor de Filipe II de Espanha e das suas pretensões suscitou múltiplas perplexidades aos seus biógrafos; não falta quem o considere um traidor da pátria, um vendido. ${ }^{50}$ Não é este o lugar para proceder a julgamentos dessa natureza nem será essa, por certo, a função

${ }^{47}$ Falla do Bispo D. Antonio Pinheyro no auto das Cortes, que S. Magestade celebrou em Thomar. Em 20 de Abril. Era de 1581. Publicado no Tomo I da Colleçam das obras portuguezas do sábio Bispo de Miranda e Leiria D. António Pinheiro.... Feita por Bento Joze de Souza Farinha, Lisboa, Na Of. de Joze da Silva Nazareth, 1785, 210-212.

${ }^{48}$ P. 212.

${ }^{49}$ Falla do Bispo D. Antonio Pinheyro no auto do juramento do Principe D. Diogo, nas mesmas Cortes. Em 23 de Abril de 1587. Publicado no Tomo I da Colleçam das obras portuguezas do sábio Bispo de Miranda e Leiria D. António Pinheiro... Feita por Bento Joze de Souza Farinha, Lisboa, Na Of. de Joze da Silva Nazareth, 1785, 213-217.

${ }^{50} \mathrm{O}$ caso mais paradigmático é o de Alfredo MATOS, cit. São sugestivos os títulos dos capítulos XI a XIII, respectivamente: "D. António Pinheiro - Bispo de Leiria e político ambíguo"; "D. António Pinheiro - Bispo de Leiria e político antinacional"; "D. António Pinheiro - Bispo de Leiria: a recompensa da traição" $(38-47)$. 
da História e muito menos dos estudos literários. Pode, quando muito, tentar explicar-se, isso sim, os passos que a tal comportamento terão conduzido o bispo de Leiria. E a explicação parece bastante plausível.

António Pinheiro desde muito cedo se tornou, como acima se disse, no orador oficial da corte ou, melhor dizendo, da Coroa. Pregador régio, orador áulico, qualquer uma destas designações lhe quadra, com inteira propriedade. Toda a sua carreira, desde o regresso de Paris, foi condicionada por essa função que, manifestamente, lhe era aprazivel. Homem de origem modesta, ao que se supõe, agradava-lhe o convívio com os grandes da Corte e a influência que nela os seus discursos iam possuindo.

Pouco a pouco, foi-se tornando, acima de tudo, um homem da Rainha, a quem influenciava e de quem dependia. O pendor anti-judaico da sua pregação na trasladação dos ossos de D. Manuel, e a que acima se aludiu já, não será alheio a essa proximidade à rainha. Terá sido ela, de resto, a conseguir-lhe a nomeação episcopal para Miranda. D. Catarina, não o esqueçamos, era castelhana. Não deve constituir surpresa que, ao contrário do que alguns chegaram a supor, Cristóvão de Moura nem sequer tivesse tido necessidade de aliciar o bispo para o partido pró-castelhano. Ele já estava, de alguma forma, aliciado. A sua proximidade em relação a D. Catarina não se alterou quando o Cardeal D. Henrique assumiu o trono. E o velho Cardeal, tanto quanto se sabe, não era desfavorável às pretensões do monarca espanhol. Ou seja, António Pinheiro, no fim de contas, mais não fez do que manter a sua linha de pensamento e de conduta, como, de resto, aconteceu com uma parte da nobreza portuguesa.

Assim viveu o ilustre portomosense e bispo de Leiria, activa e participadamente, um dos mais ricos e fecundos séculos da história portuguesa.

Mestre de Retórica, orador, homem de Igreja, articulou bem essa tríplice qualidade nos caminhos da política portuguesa da segunda metade do século XVI. A sua acção na crise sucessória não está suficientemente estudada. As cartas, poucas, e os discursos não são documentação cabalmente esclarecedora. Mais elementos hão-de ser colhidos na poeira dos arquivos, que nos permitam deslindar intrigas, acompanhar negociações, desvendar influências, compreender jogos de bastidores, pois tudo isso terá ditado o evoluir dos acontecimentos.

Do que sabemos, podemos estar certos de que D. António Pinheiro foi uma figura, se não decisiva, pelo menos preponderante. Provar como, eis o desafio que daqui pode sair para os estudiosos do Renascimento, na História ou na Literatura. 